\title{
KAJIAN PERUBAHAN TUTUPAN LAHAN DAERAH ALIRAN SUNGAI BRANTAS BAGIAN HILIR MENGGUNAKAN CITRA SATELIT MULTI TEMPORAL (STUDI KASUS: KALI PORONG, KABUPATEN SIDOARJO)
}

\author{
Aninda Nurry M.F., Ira Mutiara Anjasmara \\ Jurusan Teknik Geomatika FTSP-ITS, Kampus ITS Sukolilo, Surabaya, 60111 \\ Email : fannianinda@gmail.com
}

\begin{abstract}
Abstrak
Perubahan tutupan lahan (land cover change) ditandai dengan adanya perubahan alih fungsi penggunaan lahan. Pada daerah aliran sungai perubahan tutupaan lahan sekitar daerah aliran sungai tersebut biasanya terjadi pada daerah sisi kanan dan kiri sungai yang digunakan sebagai pemukiman atau daerah industri (pabrik). Sungai Porong sebagai bagian dari Sungai Brantas yang sudah lama beralih fungsi sebagai tempat pembuangan luapan lumpur panas Sidoarjo telah banyak mengalami perubahan. Terjadinya bencana lumpur Sidoarjo pada 29 Mei 2006 membuat suatu perubahan yang mempengaruhi kondisi air, pemukiman dan sosial ekonomi di wilayah tersebut.
\end{abstract}

Untuk mengetahui besarnya perubahan tutupan lahan daerah tersebut dapat digunakan teknologi penginderaan jauh yang berbasis citra satelit menggunakan citra Landsat 7 dan citra Landsat 8 . Penggunaan kedua citra yang berbeda tersebut dapat dikatakan sebagai citra multitemporal. Salah satu metode yang digunakan untuk mengetahui perubahan tutupan lahan yaitu dengan melakukan klasifikasi berdasarkan kemiripan maksimum (maximum likelihood). Dari hasil klasifikasi tersebut, akan diketahui perubahan tutupan lahan daerah sekitar aliran sungai Porong tahun 2002 dan 2013.

Hasil tutupan lahan di area kali Porong dari tahun 2002 dan 2013 menunjukan adanya perubahan antara lain luas sawah, luas lahan terbangun, luas lahan kosong, luas badan air (sungai), luas hutan, luas tegalan, luas tambak, dan adanya penambahan kelas lumpur panas Sidoarjo pada landsat 8 dikarenakan semburan lumpur yang berlangsung sejak tahun 2006 sehingga menghilangkan ratusan hektar sawah dan lahan terbangun. Perubahan tutupan lahan pada landsat 8 yang lain juga muncul yaitu adanya kelas pulau Sarinah yang merupakan hasil pembentukan dari buangan lumpur panas Sidoarjo yang dialirkan melalui kali Porong.

Kata Kunci: Perubahan Tutupan lahan, Citra Multitemporal, Klasifikasi Maximum Likelihood

\section{PENDAHULUAN}

\section{Latar Belakang}

Pengelolaan DAS tidak terlepas dari berbagai permasalahan, antara lain masalah penurunan sumberdaya alamiah, polusi dari berbagai sumber, serta konflik penggunaan lahan di sekitar DAS. Kerusakan DAS dapat ditandai oleh perubahan perilaku hidrologi, seperti tingginya frekuensi kejadian banjir (puncak aliran) dan meningkatnya proses erosi dan sedimentasi (Clark, 1996).

Kali Porong sebagai bagian dari Sungai Brantas yang sudah lama beralih fungsi sebagai tempat pembuangan luapan lumpur lapindo telah banyak mengalami perubahan. Dengan terjadinya bencana lumpur Sidoarjo pada 29 Mei 2006, dan kemudian pada November 2006. Pemerintah menetapkan Kali porong sebagai tempat pembuangan lumpur Sidoarjo menuju ke laut, maka fungsi kali Porong selain sebagai floodway DAS Brantas, juga berfungsi sebagai saluran untuk mengalirkan endapan lumpur. Perubahan tersebut mempengaruhi kondisi air, pemukiman dan sosial ekonomi di wilayah tersebut.

Untuk mengetahui besarnya perubahan tersebut dapat digunakan teknologi penginderaan jauh yang berbasis citra satelit menggunakan citra Landsat 7 dan citra Landsat 8. Penggunaan kedua citra yang berbeda tersebut dapat dikatakan sebagai citra 
multitemporal. Citra multitemporal merupakan citra yang memiliki resolusi temporal. Menurut Danoedoro (1996), resolusi temporal adalah kemampuan suatu sistem untuk merekam ulang daerah yang sama. Landsat (Land Satellites) merupakan tertua dalam program observasi bumi yang dipelopori oleh NASA Amerika Serikat. Pada mulanya bernama ERTS-1 (Earth Resources Technology Satellite) yang pertama kali diluncurkan pada tanggal 23 Juli 1972 dan disusul ERTS-2 pada tahun 1975 (Thoha, 2008).

Pada penelitian ini juga dilakukan kajian perubahan tutupan lahan berdasarkan hasil klasifikasi terselia pada citra Landsat 7 tahun 2002 dan Landsat 8 tahun 2013. Kajian perubahan tutupan lahan Kali Porong mengacu pada data perencanaan yang tercantum dalam Rencana Tata Ruang Wilayah (RTRW) kabupaten Sidoarjo tahun 2009-2029.

\section{Perumusan Masalah}

Rumusan masalah dalam penelitian ini adalah :

1. Bagaimana memetakan tutupan lahan wilayah Kali Porong citra Landsat 7 tahun 2002 dan citra Landsat 8 tahun 2013?

2. Bagaimana perubahan tutupan lahan di Kali Porong, Kabupaten Sidoarjo pada tahun 2002 dan 2013?

3. Bagaimana kemampuan citra satelit Landsat 7 dan Landsat 8 dalam mengidentifikasi perubahan tutupan lahan wilayah Kali Porong, Kabupaten Sidoarjo yang terjadi pada tahun 2002 sampai tahun 2013?

\section{METODOLOGI PENELITIAN}

\section{Lokasi Penelitian}

Kegiatan penelitian ini dilakukan di Sungai Porong, Kabupaten Sidoarjo. Berdasarkan data landuse Sungai Porong milik Balai Besar Wilayah Sungai Brantas dan Peta Rencana Tata Ruang Wilayah Kabupaten Sidoarjo, sungai Porong terletak di lima Kecamatan yaitu Kecamatan Tarik, Kecamatan Prambon, Kecamatan Krembung, Kecamatan Porong dan Kecamatan Jabon. Secara geografis, Sungai Porong terletak pada $112,5^{\circ}-112,9^{\circ} \mathrm{BT}$ dan $7,3^{\circ} \mathrm{LS}-7.5^{\circ} \mathrm{LS}$.

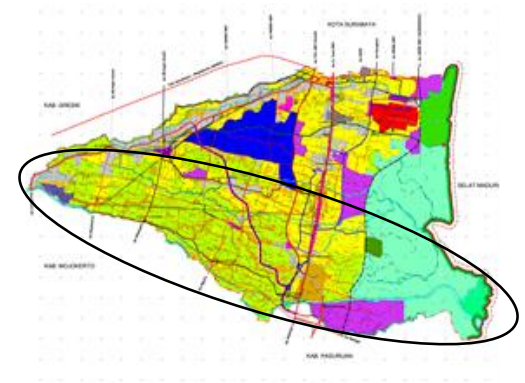

Gambar 1. Lokasi penelitian (Pemerintah Kabupaten Sidoarjo, 2013)

\section{Data Dan Peralatan}

\section{- Data}

Pada penelitian ini, data yang digunakan yaitu data citra satelit Landsat 7 tahun 2002 dan Landsat 8 tahun 2013. Data citra satelit tersebut dapat diunduh secara bebas di glovis.usgs.gov.us. Selain itu data lain yang digunakan yaitu peta Rupa Bumi Indonesia (RBI) Kecamatan Mojosari dan Porong tahun 1999 skala 1:25.000 untuk georeference pada citra serta data batas kecamatan Tarik, Prambon, Krembung, Porong, dan Jabon dengan format vektor .

\section{- Peralatan}

Peralatan yang digunakan dalam penelitian ini adalah berupa perangkat keras yaitu Personal Computer (PC) / Notebook dan GPS Navigasi serta perangkat lunak untuk pengolahan data penginderaan jauh dan klasifikasi citra satelit multi temporal.

\section{Pengolahan Data}

Pada proses pembuatan peta tutupan lahan Kali Porong tahun 2002 dan 2013 hal yang pertama dilakukan yaitu dengan melakukan koreksi geometrik pada citra dengan peta RBI sebagai data referensinya. Kemudian dilakukan pemotongan citra sesuai area studi penelitian. Untuk mengetahui perubahan tutupan lahan, metode yang digunakan yaitu klasifikasi terselia kemiripan maksimum (maximum likelihood). Hasil dari proses klasifikasi tersebut yaitu peta tutupan lahan Kali Porong tahun 2002 dan 2013. Berdasarkan hasil peta tutupan lahan wilayah Kali Porong kemudian dilakukan kajian perubahan tutupan lahan wilayah Kali Porong berdasarkan data dan perencanaan lahan berdasarkan peraturan atau ketetapan dari 
Rencana Tata Ruang Wilayah Kabupaten Sidoarjo tahun 2009-2029.

\section{HASIL DAN PEMBAHASAN}

Hasil

Hasil dari proses pengolahan dan perhitungan adalah sebagai berikut :

a. Koreksi Geometrik

Hasil Koreksi Geometrik dengan syarat nilai RMS Error 1 pixel, citra Landsat akuisisi 23 Agustus 2002 diperoleh 17 GCP dengan rata - rata RMS Error 0,6458. Sedangkan untuk citra Landsat 8 akuisisi 13 Agustus 2013 diperoleh 17 GCP dengan rata - rata RMS Error 0,6441. Berdasarkan hasil GCP, dapat dilihat bahwa posisi titik perkiraan (predicted point) tidak bergeser jauh dengan posisi titik acuan (actual point).

b. Klasifikasi Tutupan Lahan dari Citra

Klasifikasi citra dilakukan dengan menganalisis sejumlah piksel berdasarkan spektralnya. Klasifikasi yang digunakan dalam penelitian ini adalah klasifikasi terselia berdasarkan maximum likelihood.

Hasil klasifikasi pada Landsat 7 dibagi menjadi 6 kelas yaitu lahan terbangun (pemukiman, sentra industri, sentra perdagangan), sawah (sawah irigasi dan sawah tadah hujan), tegalan (tanah yang ditanami tanaman pangan tanpa sistem irigasi), badan air, lahan kosong dan kawasan perikanan (tambak). Berikut adalah peta hasil klasifikasi citra Landsat 7 tahun 2002 wilayah Kali Porong, Kabupaten Sidoarjo.

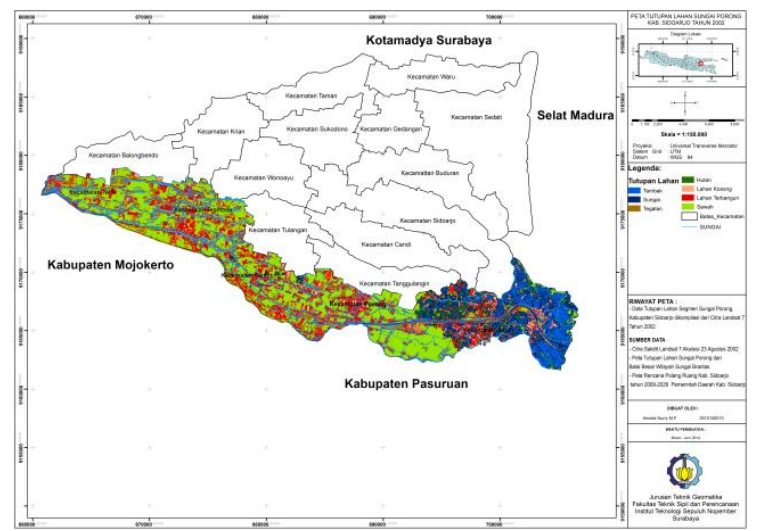

Gambar 3. Hasil Klasifikasi Tutupan Lahan Citra Landsat 7 Kali Porong, Kabupaten Sidoarjo tahun 2002
Tabel 1. Luas Area Tutupan Lahan Kali Porong Berdasarkan Hasil Klasifikasi Citra Landsat 7 tahun 2002

\begin{tabular}{lrr}
\hline Kelas & Luas $(\mathbf{H a})$ & $\%$ \\
\hline LAHAN & 5244.513 & 0.8 \\
TERBANGUN & 9100.884 & 3.3 \\
LAHAN KOSONG & 1364.632 & 5.5 \\
TAMBAK & 2801.008 & 1.3 \\
BADAN AIR & 703.05 & 5.7 \\
HUTAN & 985.258 & 9.3 \\
TEGALAN & 1023.253 & 45.0 \\
SAWAH & 21222.598 & 100 \\
\hline
\end{tabular}

Pada proses klasifikasi perubahan tutupan lahan Kali Porong pada citra Landsat 8 tahun 2013 mengacu pada peta RTRW Kabuapeten Sidoarjo tahun 2009-2029. Perbedaan acuan klasifikasi pada Landsat 8 dikarenakan perubahan tutupan lahan Sidoarjo karena adanya semburan lumpur panas Sidoarjo. Berdasarkan legenda pada peta RTRW Kabupaten Sidoarjo kelas yang dapat mewakili klasifikasi tutupan lahan pada citra Landsat 8 yaitu : Kawasan Lahan Sawah yaitu sawah dan tegalan, Kawasan Hutan (hutan bakau), Sungai, Perikanan (Tambak), Kawasan Lindung Geologi (Terdampak lumpur), Pemukiman dan Industri sebagai lahan terbangun. Berikut hasil klasifikasi citra Landsat 8 tahun 2013 wilayah Kali Porong, Kabupaten Sidoarjo:

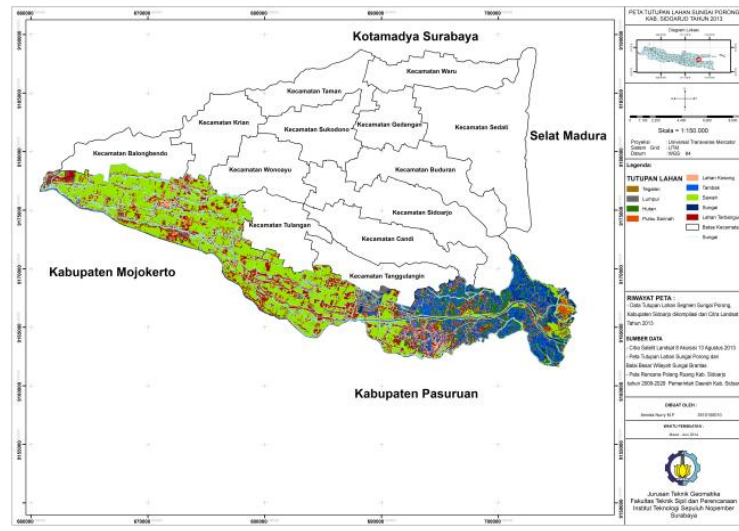

Gambar 4. Hasil Klasifikasi Tutupan Lahan Citra Landsat 8 Kali Porong, Kabupaten Sidoarjo tahun 2013 
Tabel 2. Luas Area Tutupan Lahan Kali Porong Berdasarkan Hasil Klasifikasi Citra Landsat 8 tahun 2013

\begin{tabular}{lrr}
\hline \multicolumn{1}{c}{ Kelas } & Luas $(\mathrm{Ha})$ & \multicolumn{1}{c}{$\%$} \\
\hline LAHAN TERBANGUN & 4971.816 & 23.42 \\
SAWAH & 8938.214 & 42.11 \\
TAMBAK & 2068.748 & 9.74 \\
BADAN AIR & 1742.722 & 8.21 \\
HUTAN & 1080.575 & 5.09 \\
TEGALAN & 1289.04 & 6.07 \\
LAHAN KOSONG & 180.877 & 0.80 \\
LUMPUR & 649.61 & 3.06 \\
PULAU SARINAH & 298.89 & 1.05 \\
Total & 21222.498 & 100 \\
\hline
\end{tabular}

c. Hasil Uji Akurasi Klasifikasi

Salah satu uji ketelitian interpretasi yang disarankan oleh Purwadhi (2001) dapat dilakukan dengan cara membuat matriks dari perhitungan setiap kesalahan (confusion matrix) pada setiap bentuk penutup/penggunaan lahan dari hasil interpretasi citra penginderaan jauh. Ketelitian pemetaan (MA) dibuat dalam beberapa kelas $X$ serta ketelitian keseluruhan hasil klasifikasi $(\mathrm{KH})$ yang dapat dihitung dengan menggunakan rumus :

$$
\begin{aligned}
& M A=\frac{X c r \text { pixel }}{\text { Xcr pixel }+ \text { Xo pixel }+ \text { Xco pixel }} \\
& K H=\frac{\text { jumlah pixel murni semua kelas }}{\text { jumlah semua pixel }}
\end{aligned}
$$

Keterangan :

MA :Ketelitian pemetaan (mapping accuracy)

$\mathrm{Xcr}$ :Jumlah kelas $\mathrm{X}$ yang terkoreksi

Xo :Jumlah kelas $X$ yang masuk ke kelas lain

Xco :Jumlah kelas $\mathrm{X}$ tambahan dari kelas lain

$\mathrm{KH} \quad$ :Hasil klasifikasi

Nilai KH (Ketelitian Hasil Interpretasi) pada citra tahun 2002 $=97.16 \%$, yaitu > $85 \%$ (Lillesand and Kiefer, 2009). Sehingga ketelitian klasifikasi memenuhi toleransi dan klasifikasi citra dianggap benar. Sedangkan nilai KH (Ketelitian Hasil Interpretasi) pada citra tahun $2013=89.56 \%$, yaitu $>85 \%$ (Lillesand and Kiefer, 2009). Sehingga ketelitian klasifikasi memenuhi toleransi dan klasifikasi citra dianggap benar

\section{Analisa}

a. Analisa Perubahan Tutupan Lahan Kali Porong tahun 2002 dan 2013

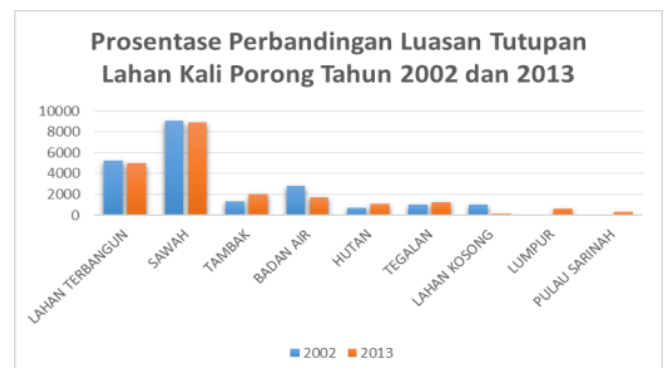

Gambar 5. Perbandingan Luasan Tutupan Lahan Kali Porong tahun 2002 dan 2013

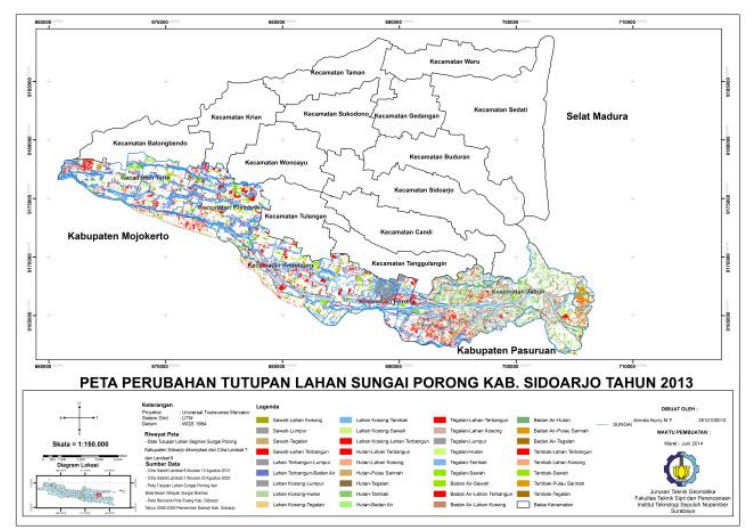

Gambar 6. Peta Perubahan Tutupan Lahan Kali Porong, Kabupaten Sidoarjo tahun 2002 dan 2013

Luas tutupan lahan pada tahun 2002 yaitu sebesar 21.222.59 Ha. Pada tahun 2013, luasan tutupan lahan menurun sebesar 21,62\% atau sebesar $1049 \mathrm{Ha}$ sehingga luas tutupan lahan Kali Porong tahun 2013 sebesar $21222.492 \%$.

Berdasarkan hasil klasifikasi tutupan lahan, terdapat perbedaan yang cukup signifikan antara tahun 2002 hingga 2013. Pada rentang waktu tersebut terdapat kejadian bencana lumpur panas Sidoarjo atau lumpur LAPINDO pada tahun 2006 yang menghilangkan ratusan hektar sawah, lahan terbangun, tegalan dan lahan kosong. Akibat bencana tersebut, pemerintah Kabupaten Sidoarjo mengalirkan luapan lumpur LAPINDO tersebut melalui kali Porong yang 
kemudian digunakan sebagai reklamasi suatu daratan yang terbentuk dari hasil sedimentasi lumpur tersebut. Hasil reklamasi tersebut kemudian diberi nama Pulau Sarinah yang kurang lebih luasnya mencapai 80 hektar sejak tahun 2007. Oleh karena itu penambahan kelas lumpur dan pulau Sarinah pada klasifikasi Landsat 7 ke Landsat 8 sangat penting dikarenakan luas yang dihasilkan kedua kelas tersebut besar.

b. Kajian Kesesuaian Klasifikasi Citra Landsat 8 tahun 2013 dengan Rencana Tata Ruang Wilayah Kabupaten Sidoarjo tahun 20092029

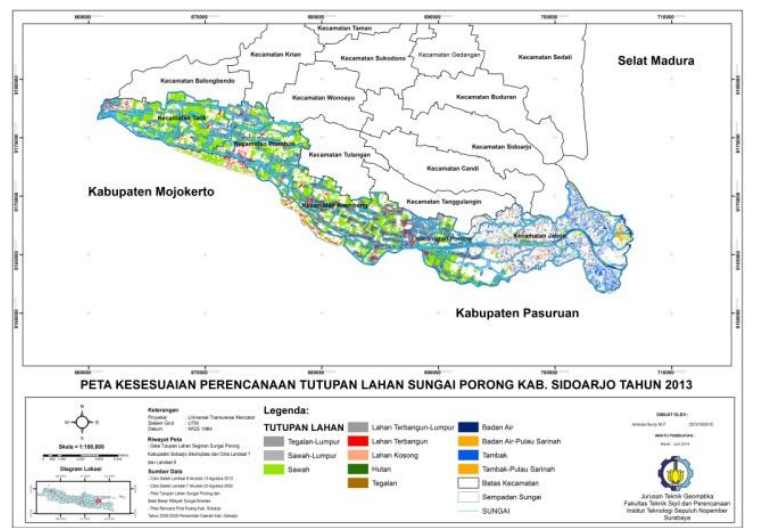

Gambar 7. Peta Kesesuaian Perencanaan Tutupan Lahan Sungai Porong Kab. Sidoarjo tahun 2013

Hasil kajian tutupan lahan kali Porong tahun 2002 dengan peta rencana pola ruang/Rencana Tata Ruang Wilayah kabupaten Sidoarjo tahun 2009-2029 mengidentifikasi bahwa kelas yang sudah sesuai dengan data perencanaan yang tercantum pada RTRW kabupaten Sidoarjo tahun 2009-2029 yaitu kelas sungai dan lumpur panas Sidoarjo. Sedangkan pada kelas hutan, sawah dan tegalan, tambak justru melebihi perencanaan yang ditetapkan oleh pada RTRW. Pada RTRW juga tidak ditetapkan data perencanaan yang pasti untuk kelas pulau Sarinah dan lahan kosong atau terbuka

\section{PENUTUP}

Berdasarkan hasil penelitian di atas, dapat disimpulkan sebagai berikut :

1. Luas tutupan lahan kali Porong di kecamatan Tarik, Prambon, Krembung, Porong, dan Jabon tahun 2002 yang paling besar adalah kelas sawah dan terkecil adalah hutan.

2. Luas tutupan lahan kali Porong di kecamatan Tarik, Prambon, Krembung, Porong, dan Jabon tahun 2013 yang paling besar adalah kelas sawah sedangkan luas tutupan lahan terkecil adalah kelas lahan kosong.

3. Analisa perubahan tutupan lahan di area kali Porong dari tahun 2002 dan 2013 antara lain: sawah, lahan terbangun, lahan kosong dan badan air mengalami penurunan. Sementara kelas tambak, tegalan dan hutan mengalami peningkatan

4. Hasil tutupan lahan kali Porong tahun 2002 dengan peta rencana pola ruang/Rencana Tata Ruang Wilayah kabupaten Sidoarjo tahun 2009-2029 yaitu kelas sungai dan lumpur panas Sidoarjo. Sedangkan pada kelas hutan, sawah dan tegalan, tambak justru melebihi perencanaan yang ditetapkan oleh pada RTRW.

\section{DAFTAR PUSTAKA}

Clark, N. (1996). Evolutionary dynamics and sustainable development: A system approach. Cambridge: Cambridge University Press

Danoedoro, P, 1996. Pengolahan Citra Digital. Fakultas Geografi, Universitas Gadjah Mada, Yogyakarta.

Pemerintah Kabupaten Sidoarjo. 2013. Peta Rencana Pola Ruang Kabupaten Sidoarjo. www.sidoarjokab.go.id. Diakses pada tanggal 16 Mei 2014 pukl 10.41

Thoha, A. S. (2008). Karakteristik Citra Satelit. Dikutip pada tanggal 10 Oktober, 2013, dari:http://abuhaniyya.files.wordpress.c om/2009/02/karakteristik20citra20sateli t6.pdf 